paper by Professor Trowbridge, read before the National Academy, and noticed in Science of Nov. I 8, I887. Those who heard or have read Professor Trowbridge's paper will remember that it reported the discovery by his son of a peculiar structure in the primary wing-feathers of soaring birds, by which they are locked when expanded, and are thus maintained in position without muscular effort. This structure is shown only in the primary feathers, and is therefore a character belonging to the last division of the arm.

Professor Wyman, in the note referred to, describes " a peculiar arrangement of the bones and ligaments in the wing of the pintailed duck, by which, while the wing is fully extended, all the segments of this extremity are fixed and retained in position independently of muscular action." His account of the mechanism of the wing is as follows:-

"The structure of the articulations of the elbow and wrist is such, that during flexion and extension the radius advances and recedes upon the ulna, carrying with it the upper carpal bone, and this last the hand: in this way flexion and extension of the bones are effected. The lower carpal bone is attached to the upper by strong ligaments: consequently, when the upper carpal bone is drawn over the extremity of the ulna as the radius recedes, the lower one is drawn up between the hand and the extremity of the ulna, and, acting as a wedge, maintains the hand extended, until it is displaced by the reversed action of the radius." This structure, according to Professor Wyman, shows how the extension of the bony framework of the wing may be maintained indefinitely without fatigue. The structure of the primary wing-feathers described by Professor Trowbridge indicates that they too may be locked in position, and thus the rigidity of the wing may be maintained automatically to its extremity.

None of the members of the National Academy who took part in the discussion which followed the reading of Professor Trowbridge's paper seemed to have any knowledge of this discovery of Professor Wyman; and it was remarked, that, while the facts cited tby Professor Trowbridge seemed to explain the automatic extension of the primaries which are appendages of the manus, the rigidity of the arm itself, apparently manifested in the flight of soaring birds, was yet unaccounted for. That missing link was supplied by Professor Wyman, but, from his characteristic modesty, so quietly announced that it has been known to few.

The case cited by me at the meeting of the National Academy was a turkey-buzzard, shot when soaring over the prairies in the Sacramento valley. Its wings remained rigidly extended, and it "descended slowly like a parachute and settled in the grass very near me, quite dead; even then the wings remaining expanded.

Professor Storer gives other interesting examples. He says, "Upon the New England seaboard nothing is more familiar to old gunners than the phenomenon that a bird shot in mid-air will often 'set his wings' and scale down toward the horizon, to reach the water dead, often at a great distance from the boat whence the shot was fired. Even in childhood I remembered to have won'dered, when 'assisting' at the shooting of duck and coot, as to the meaning of the not infrequent exclamation, "That fellow has set this wings; watch him!'”

Dr. Storer writes that he was present at the meeting of the Boston Natural History Society, Sept. I, I 855, when Professor Wyman exhibited his preparation of the duck's wing, and gave an explanation of its structure which seemed a demonstration.

Now, if some good anatomist would review the subject again, combine the results reached by Professor Wyman and Professor Trowbridge, and illustrate his memoir with good figures, he would make an important contribution to biological science.

J. S. NEWBERRY.

New York, Dec. ro.

\section{The Origin of the Tritubercular Type of Mammalian}

\section{Dentition.}

Professor COPE has fully demonstrated that the molar teeth of many divisions of the higher mammalia are derived from the tritubercular type of molar which is so abundant in the mammals of the Puerco, or lowest eocene period. $\mathrm{He}$ has further ('Origin of the Fittest,' p. 347) shown that the tritubercular type may be traced back to the single cone of the reptilian crown by the follow- ing succession: ' first, a simple cone or reptilian crown alternating with that of the other jaw; second, a cone with lateral denticles; third, the denticles to the inner side of the crown forming a threesided prism, with tritubercular apex, which alternates with that of the opposite jaw,' etc. In the last meeting of the American Association for the Advancement of Science, Professor Cope applied this succession to the origin of what he has called the 'tubercular-sectorial ' molar, citing the molars of Owen's genus Spalacotherium as an instance of the transformation into the tritubercular crown in process. I had independently arrived at the same conclusion, and, moreover, found that the origin of the tritubercular crown in all its various stages could be traced in the mesozoic mammalia. This is traced in a memoir now publishing by the Philadelphia Academy. I am glad to be able to confirm Professor Cope's views in every particular, for his numerous and suggestive papers upon the mechanical genesis of tooth forms have placed comparative anatomists generally in his debt. Among the mesozoic mammalia the simple large cone with small lateral denticles is seen in the American triassic genus Deomotherium. From the same beds Microconodon furnishes a more advanced stage in the growth of the lateral denticles into cusps. The mandibles of Jurassic genera Phascolotherium, Menacodon, Spalacotherium, furnish three stages of the rotation inwards of the lateral cusps, accompanied probably by the rotation outwards of the lateral cusps in the upper jaw. In Stylodon this process is complete, the teeth being distinctly tritubercular, with the addition of a posterior heel, the upper molars reversing the pattern of the lower. In another line of genera the lateral cusps show no tendency to rotate inwards, but continually augment in size, such as Triconodon and its successors, leading to the modern Thylacinus type of molar. In Amphitherium and many other genera it appears as if the posterior lateral cusp had never been acquired, and the crown is re-enforced by the inward extension of the cingulum, as seen in an early stage in Diplocynodon. In Kurtodon, by the union of the external tubercles in the upper jaw, we observe a columnar molar of the rodent type. It now appears as if we should soon be in possession of sufficient data to trace the entire history of the multi-cuspid and multi-fanged mammalian molar from the single reptilian cone and fang.

HENRY F. OSBORN.

Princeton, N.J., Dec. x2.

\section{Iroquois and Eskimos.}

IN connection with the dicussion which has recently appeared in Science on the ancient relations of the Iroquois and Eskimos, a passage which I recently came across in the manuscripts of the Moravian missionary Christopher Pyrlæus is worthy of note.

The active work of Pyrlæus was between 1740 and $175^{\circ}$, and he became an accomplished scholar in one or more of the Iroquois dialects. In July, I749, the Iroquois sent a deputation to a council at Philadelphia, when Pyrlæus acted as interpreter. In his notes of his conversations with the deputies he has the following:-

"Tschiechrohne heissen die Grönlander ; . . . Tschie, ein Seehund. Die drei obgenannte Seneker wussten nicht nur von den Grönlandern, sondern auch ihrer Contry (sic), Landsart, Kleidung, Nahrung," etc.

Of course, Pyrlæus used the term 'Greenlanders' as generic for 'Eskimos.' Evidently the Iroquois, who pushed their war parties to the south as far as the present State of Louisiana, carried their excursions also as far north as the shores of the Frozen Ocean.

Media, Penn., Dec. 7 .

D. G. BRINTON.

\section{The Sioux.}

In your issue of Nov. 25 (p. 264) your correspondent from Lexington, Mo., says, "The Sioux call themselves Lah-ko-ta." In this he is correct ; but when he adds, " not Dakota," he is in error. The sounds of $l$ and $d$ are interchanged among certain Dakota dialects. The Sioux who dwell east of the Missouri say Dakota, while most of those on the west side (Tetons) say Lakota (vide Riggs's Grammar and Dictionary of the Dakota Language, p. 133).

In giving the meaning of the name as 'cut-throats,' he is at variance with the best authorities on the Dakota language.

Washington, D.C., Nov. 26. 